University of Nebraska - Lincoln

DigitalCommons@University of Nebraska - Lincoln

Mammalogy Papers: University of Nebraska

State Museum

Museum, University of Nebraska State

April 1967

Notes on Some Mammals from Nebraska

Jerry R. Choate

University of Kansas, Lawrence

Hugh H. Genoways

University of Kansas, Lawrence, h.h.genoways@gmail.com

Follow this and additional works at: https://digitalcommons.unl.edu/museummammalogy

Part of the Zoology Commons

Choate, Jerry R. and Genoways, Hugh H., "Notes on Some Mammals from Nebraska" (1967). Mammalogy Papers: University of Nebraska State Museum. 56.

https://digitalcommons.unl.edu/museummammalogy/56

This Article is brought to you for free and open access by the Museum, University of Nebraska State at DigitalCommons@University of Nebraska - Lincoln. It has been accepted for inclusion in Mammalogy Papers: University of Nebraska State Museum by an authorized administrator of DigitalCommons@University of Nebraska Lincoln. 


\title{
Notes on Some Mammals from Nebraska
}

\author{
JERRY R. CHOATE and HUGH H. GENOWAYS
}

In the course of field studies in Nebraska, several noteworthy records of mammals have been obtained that add significantly to their known distribution, as shown by Jones (1964) in his "Distribution and taxonomy of mammals of Nebraska." In the following accounts all catalogue numbers refer to specimens deposited in The University of Kansas Museum of Natural History. Parenthetical page references refer to Jones (1964) unless otherwise indicated.

Didelphis marsupialis virginiana Kerr, 1792.- Heretofore the westernmost record of occurrence of the opossum in Nebraska was from Alliance, Box Butte County (p. 61). As indicated on his map showing the distribution of the opossum in Nebraska, Jones (p. 59) believed that dispersal westward to Box Butte County probably occurred along the Niobrara River.

On 6 January 1966, an adult male opossum (103120) was obtained from a place three miles north of McGrew, Scotts Bluff County. This locality, approximately 47 miles west-southwest of Alliance, is about 120 miles upstream on the North Platte River from Paxton, Keith County. The latter was the westernmost locality of record for the opossum along the Platte River in Nebraska (p. 61). The occurrence of Didelphis marsupialis in Scotts Bluff County probably indicates that westward dispersal of this species into Goshen County, Wyoming (Brown, 1965:142143), has occurred through western Nebraska along the North Platte River rather than southward from a locality listed by Long (1965:515$516)$ in the watershed of the Cheyenne River in Converse County, Wyoming.

Sorex cinereus haydeni Baird, 1858.-The southernmost record of the masked shrew in Nebraska given by Jones (p. 65) was $13 / 4$ mi. S Kearney, in the valley of the Platte River, Kearney County. He (p. 62) stated that there was only one record of $S$. c. haydeni from south of the Platte River drainage ( $5 \mathrm{mi}$. E Rising City, Butler County) and this was from only "a few miles south of the divide between the drainages of the Platte and Blue rivers."

On 21 November 1965, two male and two female masked shrews were collected from two places in Clay County-11/2 mi. E Harvard

Transactions of the Kansas Academy of Science, Vol. 69, Nos. 3-4, 1966. Published April 25, 1967. 
(103121) and 7 mi. E Harvard (103122-24). On 19 December 1965, three males were collected from two additional localities in the same county-1 mi. N, $3 \mathrm{mi}$. W Saronville (103125-26) and $1 \mathrm{mi}$. S Saronville (103127). On 3-4 April 1966, two males and one female were trapped from three places in the vicinity of Crete, Saline County, as follows: 11/2 mi. N, 3 mi. E Crete (105075); 2 mi. E Crete (105076); $21 / 2$ mi. S, 3 mi. E Crete (105077).

All the above-mentioned localities are in the drainage of the Blue River. The last locality listed (the southernmost) is 44 miles southsoutheast of the only previous record of occurrence in the drainage of the Blue River ( 5 mi. E Rising City), and only 40 miles north of the KansasNebraska border. Possibly Sorex cinereus will be found along the Big Blue River in northern Kansas.

Eptesicus fuscus pallidus Young, 1908.-On 28 July 1966, a male big brown bat (105223) was obtained from a warehouse in Bayard, Morrill County. This specimen is a young of the year as evidenced by unfused phalangeal epiphyses. It is the first bat of any species reported from Morrill County.

Onychomys leucogaster breviauritus Hollister, 1913.-According to Jones (p. 207), the northern grasshopper mouse is an uncommon inhabitant of eastern Nebraska because the original prairie has been turned for agricultural purposes. He listed specimens from Lancaster and Wayne counties as the easternmost in Nebraska.

On 3 April 1966, two pregnant females (105085-86), one with four embryos and the other with five, were obtained $1 / 2 \mathrm{mi}$. N, $3 \mathrm{mi}$. W Wilber, Saline County. This locality is within the probable range of the species as mapped by Jones (p. 208), but the specimens are the first to be recorded from Saline County. They were trapped in a roadside ditch, almost denuded of vegetation, adjacent to a grain field.

Sigmodon hispidus texianus (Audubon and Bachman, 1853).-The first specimens of the hispid cotton rat from Nebraska were reported by Jones (1960:132) from along the Little Nemaha River 31/2 mi. S, $1 \mathrm{mi}$. W Dawson, Richardson County. Genoways and Schlitter (1967) reported the second locality of record for the state and the northernmost for the species-a single specimen taken 37/8 mi. S, 11/16 mi. E Holstein, Adams County. They summarized data on the northward movement of the cotton rat into Nebraska and Missouri.

On 12 August 1966, an adult female (105938) and an adult male (105939) were obtained by Messrs. Elwin and Harold Tuner from the 
same locality as that reported by Genoways and Schlitter (loc. cit.). The female contained 11 embryos that measured $8 \mathrm{~mm}$. in crown-rump length.

Synaptomys cooperi gossii (Coues, 1877).--Jones (p. 220) stated that in eastern Nebraska the southern bog lemming is an uncommon inhabitant of locally favorable habitats.

On 3-4 April 1966, two specimens were obtained by the authors from localities in Saline County-1 mi. S, $3 \mathrm{mi}$. E Crete (105107) and 3 mi. S, 2 mi. E Crete (105108). Although these two localities are within the suspected range of Synaptomys cooperi in Nebraksa (Jones, p. 220), the specimens are, to our knowledge, the first to be reported from Saline County.

Microtus pennsylvanicus pennsylvanicus (Ord, 1815).-Previously, the meadow vole was not known to occur south of the drainage of the Platte River in Nebraska excepting in the eastern part of the state, where it was reported from three localities in the northern part of the Blue River drainage by Jones (p. 230). The southernmost locality of record listed by him (p. 231) was 4 mi. N, 2 mi. E Hastings, Adams County.

In the autumn of 1965 and spring of 1966, we collected 36 specimens of this vole as follows:

Adams County: 9 mi. S Hastings (103189).

Clay County: 11/2 mi. E Harvard (103190-94); 1/2 mi. $\mathrm{N}$ Inland (103195-96); $1 \mathrm{mi} . \mathrm{N}, 5 \mathrm{mi}$. W Saronville (103202); $1 \mathrm{mi}$. N, 3 mi. W Saronville (103203-205); 1 mi. N, 2 mi. W Saronville (103206); 1 mi. N Saronville (103207); 1 mi. S Harvard (103197-201); 1 mi. S Saronville (103208-210).

Fillmore County: 2 mi. N, 2 mi. E Fairmont (10509596).

Saline County: 2 mi. N, 21/2 mi. E Crete (105097-98); $11 / 2$ mi. N, 3 mi. E Crete (105099); 11/2 mi. S, 3 mi. E Crete (105100); $21 / 2$ mi. S, 3 mi. E Crete $(105101-102) ; 5$ mi. S, $3 \mathrm{mi}$. E Crete (105103-104); 81/2 mi. S, $3 \mathrm{mi}$ E Crete (105105); 1 mi. N, 3 mi. W Wilber (105106).

York County: 4 mi. S York (105093-94).

All localities listed above are south of the Platte River in the drainage of the Blue River. The large number of specimens collected indicates the abundance of Microtus pennsylvanicus in this area, which is south of the known range of the species in Nebraska in that our speci- 
mens from Clay, Fillmore, Saline, and York counties are the first to be reported therefrom.

Jones (p. 230) stated that the range of M. p. pennsylvanicus in Nebraska approximated that of Sorex cinereus haydeni. As in the case of $S$. cinereus, the meadow vole eventually may be found to occur as far south as Kansas in the drainage of the Blue River. This species already has been reported from Jewell County, Kansas (Fleharty and Andersen, 1964:129), in the drainage of the Republican River.

Two females obtained on 20 November 1965 in Clay County (103195 and 103196) were pregnant, one with three and the other with five embryos. Seven of nine females collected in Fillmore, Saline, and York counties on 2-4 April 1966 were pregnant, carrying an average of 4.6 (4-5) embryos.

\section{Literature Cited}

BROWN, L. N.

1965. Status of opossum, Didelphis marsupialis, in Wyoming. Southwestern Nat., 10:142-143, April 30.

Fleharty, E. D., and K. W. ANDERSEN

1964. The meadow vole, Microtus pennsylvanicus (Ord) in Kansas. Trans. Kansas Acad. Sci., 67:129-130, June 12.

Genoways, H. H. and D. A. Schlitter

1967. Northward dispersal of the hispid cotton rat in Nebraska and Missouri. Trans. Kansas Acad. Sci., this issue.

JONES, J. K., JR.

1960. The hispid cotton rat in Nebraska. Jour. Mamm., 41:132, February 20.

1964. Distribution and taxonomy of mammals of Nebraska. Univ. Kansas Publ., Mus. Nat. Hist., 16:1-356, pls. 1-4, 82 figs., October 1.

LoNG, C. A.

1965. The mammals of Wyoming. Univ. Kansas Publ., Mus. Nat. Hist., 14:493-758, 82 figs., July 6.

-Museum of Natural History, The University of Kansas, Lawrence. Transmitted September 29, 1966. 